\title{
Truth and authority in Herodotus' narrative: false stories and true stories
}

\section{Introduction}

How do you work out which tales and which narratives to believe in a society where memories and traditions were dependent on different groups, individuals or communities being willing to remember them, or on poets to commemorate or enshrine a version whose verse might help preserve it a little longer? In which the vagaries of memory as well as the manner of telling and retelling could always alter the narratives? This volume encourages us to consider Herodotus both as a 'scientist' and as a narrator, and the two can interlock in the question of the search for what the historian considered the truth about the past, the question of how he sifted the traditions and accounts, and why he decided on one version rather than another. ${ }^{1}$ There are competing authorities: the authority of tradition by which I mean accepted and enshrined tradition ('the Aeginetans say this') the authority of the poet, and the authority of the enquirer and historian who may (or may not) use critical methods. With myth and legend, you could rationalise and remove the fantastical elements to create a more plausible version, and various writers did this in their individual ways (Hellanicus, Thucydides). For the recent past, the irony is that it could be considerably more complex for an enquirer who might encounter large numbers of witnesses, numerous angles of experience, and competing city-state traditions.

This paper started from an interest in the false stories which Herodotus tells us in the narrative of the Persian Wars, and which he then deliberately refutes with a variety of methods, adducing likelihood, proof and witnesses. The 'New Simonides' has, however, added a new dimension, as it reveals even more clearly than the numerous Simonidean epigrams how immediately after the Persian Wars a poetic celebration could heroise and elevate certain events in such a way as to render them almost beyond recognition. We are familiar with Herodotus'

1 By 'scientist', I mean the 'proto-science' of the quest to find out about the nature of the world, the cosmos, geography, the nature of man, though the methods of the latter half of the 5 th c. are often far from what would now be considered scientific.

2 See Luraghi 2001 for a sensitive and persuasive interpretation of such expressions. 
treatment of tales which are in some way 'myths', traditional tales set in the very distant past, and with the varieties of credulity, critique, and scepticism on offer, as well as with the retelling of stories to make moral points even if they were not strictly verifiable, and with the use of subtle framing devices. ${ }^{3}$ The story of Rhapsinitus and the thief is declared unlikely at several points, ending with a declaration that his principle was to record $\tau \dot{\alpha} \lambda \varepsilon y o ́ \mu \varepsilon v \alpha$ (2.121-122.1). The difficulties of knowing with certainty about periods of the really distant past are brought out in the remarks about Polycrates in comparison to Minos: Polycrates, 'the first who we know of the Greeks who intended a thalassocracy, except for

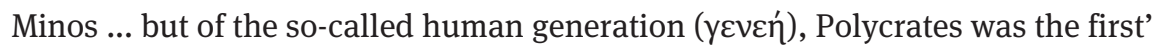
(3.122.2). Herodotus both emphasised and distanced himself from the possibility of attaining knowledge about these very distant generations, while it is interesting that Thucydides not only had fewer qualms about Minos, but also exercised all his rationalising skill to render Minos part of his geo-political vision of early Aegean history and thalassocracies. ${ }^{4}$ Herodotus' proem started with stylised and rationalised legends - and without the gods - in what was perhaps a parody of the rationalising methods used to create history from myth, and then turned to what we really 'know' (I 5.3). Yet he rationalised the Trojan War with the argument that Helen spent the duration of the war not in Troy but in Egypt. ${ }^{5}$ The critical and rationalising writer of these narratives offers an obvious point of comparison with the writer who shows a familiarity with the new developments of critical intellectual activity of the second half of the fifth century. ${ }^{6}$

In order to tease out more of his methods and approach to 'true stories' and 'false stories', we concentrate on two case studies where there exist both poetic celebration and Herodotus' narrative: the earliest antecedents of the Thera/Cyrene colonisation in Herodotus and Pindar, and the march up from Sparta through the Peloponnese to the battle of Plataea. The assumption is easily made that distortions, heroisation and fantastic elevation are really only a problem for the historians dealing with the distant myths and times of origins (compare Thucydides' strictures about the poets' elaborations, referring mainly to epic (1.21.1)). Yet the 'New Simonides' makes it remarkably clear that even events well within living

3 Cf. Baragwanath/Bakker 2012b, esp. 31 ff., for framing techniques for aetiologies and myths.

4 It is interesting, incidentally, that later Athenian historians of the 4th and early 3rd c. offered variations of the Theseus and Minos legends with an astonishing variety of rationalisation: in other words, they could not bear to omit them.

$5 \quad 2.112-120$, wound up with enquiries from the Egyptian priests.

6 On this latter aspect, see Thomas 2000 and bibliography; Lateiner 1986; and Grintser in this volume. 
memory - indeed merely a few years before - were in the process of being obliterated and transformed into something quite different. In other words the very recent past might paradoxically be even harder to ascertain than the distant. We can make a series of interlocking comparisons here: between the treatment of the recent past by poet and by historian; of recent and distant, mythical past; between local knowledge and therefore local authority as opposed to the historian's view of plausibility; and between local claims versus those of other cities and groups. In neither case did Herodotus make any special claims to have unearthed the truth or provided special testimony - he simply told the narratives as if apparently content to repeat the tales without protest. But the poetic narratives preserve startlingly different versions which give us pause, and which provide the patina of age, and epic resonance, to both recent and distant events.

It is never quite so simple that some periods are just beyond certainty. ${ }^{7}$ While Minos belonged to the terrain of uncertainty, the recent past could also present difficulties, and Herodotus shows an awareness throughout the Histories of the bounds of knowledge. Difficulty is not a straightforward function of the passing

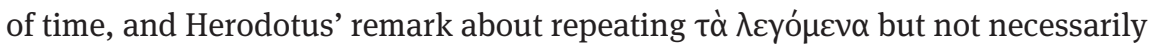
believing them in Book 7 was made in connection with recent Argive actions

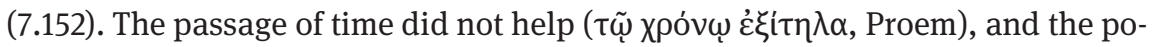
ets tended to exaggerate (Thuc. 1.21.1). Yet the false stories connected with the Persian Wars which Herodotus tells in order to refute them make it intriguingly clear that Herodotus was alert to 'false tales' about any period, showing his judgment as an impartial historian and narrator.

The Persian Wars themselves could present problems of 'truth', for there the historian had to confront problems of a different order, the countless competing versions of polis-centred narratives, and claims of bravery and success. If a polis was lucky it could transport its version into the poetic realm and its achievements could start to become assimilated to the heroic age. In the 'New Simonides', ironically, we can see the very process by which very recent events could be turned into myth even whilst surviving participants were very much alive. Simonides' elegy seems to have created a heroising, myth-like and elevated narrative. Herodotus never mentioned this elegy, but we can compare his narrative more sharply, and here, I argue, we may surmise that his narrative sought to diminish epic elevations such as these. His iotopín was concerned here, as with Minos, to diminish the poetic exaggerations and simplifications of this celebratory ode - and others

7 See recent emphasis on this in Baragwanath/Bakker 2012b; cf. 25 'Hdt's subtle and deliberate exposure of the "problem with Minos" ... would be in keeping with Hdt's more general staging of uncertainty about the terrain of myth'. 
like it - and the sentiments it encouraged. He did this by sheer narrative depth, detail and sureness about what he was narrating.

We focus, then, on two instances where there still exist poetic treatments parallel to Herodotus' treatment of the same or similar events: (1). The distant antecedents of the colonisation of Cyrene going right back to the Minyae concern the past we tend to call mythical, the time of origins. The tales of the very ancient origins of Thera and her colony Cyrene were treated both by Herodotus and Pindar in Pythian 4 and Pythian 5. We will concentrate on the pre-Theran period before the Minyans had even set out for Thera to make their second attempt to found a new settlement. (2). The very recent past of the Persian Wars, particularly the crucial developments before the battle of Plataea as a result of which the Spartans finally decided to join the Athenians and others in the final great battle of central Greece. This was treated in one of the less fragmentary sections of the 'New Simonides' and Herodotus Book 9. What emerges, I hope, is how, while even recent events could become transformed into a glorious heroising narrative, Herodotus' account of the Plataea campaign must have been written in awareness of the way it was in danger of turning into unassailable myth (just as was the battle of Salamis for the Athenians). Herodotus shared Thucydides' scepticism concerning the poets' elaborations, but he drew the lines in different places and did not engage in open polemic.

Some instructive comparisons can be made here. We cannot underestimate the sheer authority of tradition, of the 'traditional', and of the very distant past when it has been enshrined in poetic form. Genre, occasion and purpose helped form Pindar's presentation of early Theran history. We may also compare the authority of the poet with the historian's, and the conflict between the two distinct forms of authority. In the case of the Simonides elegy, the verse will have tried to enshrine a particular version in people's memories. If Simonides' elegy meant to celebrate, memorialise and heroise the Plataea victors, apportioning a form of Homeric $\kappa \lambda \varepsilon \dot{c} \circ$, Herodotus' account seems to have a quite different purpose and type of authority. In some ways, it diffuses and fragments any $\kappa \lambda \varepsilon \dot{\varepsilon}$ ऽ that was being gained, producing a fundamentally non-Homeric narrative that spoke to different concerns. It will be argued that Herodotus was trying here to cope with, refute, complicate and undermine the kind of memorial and $k \lambda \varepsilon^{\prime}$ os that the poetic commemorations sought to create. He does indeed hint at the Homeric quest for $\kappa \lambda \varepsilon \varepsilon_{0} \zeta$ in the Proem, as is well known; but the Proem also hints at the need to use judgement and proof in the less Homeric sense in the quest for what one can 'know' to be true (1.1-5, esp. the end of 1.5). There are competing forms of $\kappa \lambda \varepsilon^{\prime o \varsigma}$ and truth at work here. 
We may also consider the contrast between the recent past from which much information and misinformation was still available, and the very distant past which had been 'preserved', fixed or actually created, through processes of retelling, poetic treatments and the more or less conscious selectivity of remembering and retelling for the numerous interests of various groups (the Battiad dynasty; Therans, Spartans, Minyans etc.). It is worth stressing from the outset that such tales and traditions which purport to go back to the distant past will inevitably be a combination of individuals' accounts, traditions thought to be very old, communal accounts which seem traditional but with are inevitably influenced by later generations and circumstances of retelling, and poetic or ritual-based accounts, and that even the 'memories' of individuals were probably influenced by the wider surrounding 'communal' traditions and the priorities of their society. ${ }^{8}$ It is striking how Herodotus' account of the Persian Wars contains several false stories that he tells at length only to refute them, from the stories about Scyllies the diver, to divine intervention, or undignified behaviour on the part of various Greek states (below). Not all can be categorized simply as polis boasting and jingoism, for there were also sensational and exotic tales of wealth, disappearances and stereotypical Persian behaviour (also refuted). So anecdotes, carefully preserved and remembered versions, official narratives and memorials, and individual and family tales were all jostling together. How was an historian to decide what was true, false, plausible, probably true, or probably not true? The distant past would be simpler in some respects, having been polished and worn down by selective retellings or a single poetic version which would crystallise a single version. The recent past of the Persian Wars was still part of the messy experience of men still alive, affecting their progeny, and energetically celebrated by cities, groups and individuals. The 'New Simonides' shows in one example part of the process by which, very shortly after events with thousands of witnesses and participants, the poet and his patrons tried to construct a better and more heroic version: so here the inevitable partiality and messiness of memories and anecdotes about the very recent past collide with the stylised and almost Homeric memorialisation.

8 For the complexity of memory, memorial and tradition, cf. from a vast range, Cubitt 2007, Fentress/Wickham 1992; Halbwachs 1925, 1950; Vansina 1985; Assmann 2011; orig. 1992 relied overly on institutionalised 'memory'; Thomas forthcoming. 


\section{Cyrene and Thera: Pindar Pythian 4 and Herodotus}

Pythian 4, the longest of Pindar's odes, forms a monumental celebration for the royal house of the Battiads of Cyrene. Tied to the royal house and Arcesilaus' victory, it has all the power and authority of the Muse, the epinician elevation and the epic grandeur of the narrative of the quest for the Golden Fleece. Despite the hints at the end about wounds in the city (270-276), you would not guess from this ode alone that the monarchy was to be overturned just a few years later. ${ }^{9}$

Historians tend to be more interested in the Battus/Theran settlement in Cyrene, the episode most amenable to comparison between legends and tales about colonisation and the historical reality on the ground. What is of interest here are the very remotest origins of Cyrene which enable us to compare Herodotus on the Minyae (4.145 ff.) and Pindar on a period which by every reckoning must count as a mythical age, and which forms part of what Malkin called 'the Sparta-TheraCyrene chain'. ${ }^{10}$ Pythian 4 takes the antecedents of Cyrene right back to Medea and Euphemos, one of the Minyae and regarded as the remote ancestor of Battus. Early in the ode Medea makes a prophecy which calls upon a 'son of Polymnestus' (i.e. Battus) to found the city, 'and to fulfil in the seventeenth generation that word spoken on Thera by Medea, which the high-spirited daughter of Aietes and queen of the Colchians had once breathed forth' (9ff.; Medea's speech, 11-56). Thus the origins of the Battiads of Cyrene are traced right back to the period of the voyage of the Argo. The Argonauts' land journey to Lake Tritonis in Libya and the clod of earth legitimise the claim to the land of Libya (26-37). The oracle of Apollo at Delphi was also celebrated, when Battus went to consult the oracle about the problem of his speech (53, 59 ff.), and Apollo spontaneously foretold the foundation of Cyrene. It is also worth noting that Pindar's Pythian 5 also included a pre-Theran foundation of Cyrene by the sons of Antenor, the Antenoridae, Trojans who fled Troy with Helen when Troy burned, and who were still honoured in Cyrene (5.80-85). ${ }^{11}$ It also added more on Battus himself.

9 See Braswell 1988, Intro. on political context and the political significance of the myths.

10 Malkin 1994, 176. Giangiulio 2001 offers a full and significant discussion of the Cyrene foundation legends, with further refs to vast bibliography; 128f. compares Hdt. and Pindar. Aly 1921 offers a suggestive discussion with important parallels for the 'Märchen'. See also Zali in this volume, pp. 134-137.

11 On these mysterious Trojans, see Malkin 1994, 52-7 and further bibliography there; on the nymph Cyrene and why she was not strictly a founder, Malkin 1994, 173. 
We can assume that the sponsoring of Pythian 4 by Damophilus of Cyrene for the Cyrenean Arcesilaus must mean that the versions of these myths had firm backing in Cyrenean legend, and especially in the official Battiad version of their role in the history of Cyrene. The very presence of the monarchy will have helped solidify and preserve the tradition, and local poetry may have helped crystallized this. ${ }^{12}$ Extraordinarily, then, across the two odes we are given a double rooting of Cyrene in two major Panhellenic legends, the voyage of the Argo with its story of Medea, and the fall of Troy with Antenor. This all traces the family of Arcesilaus right back to Euphemus the Minyan. Euphemus himself was an Argonaut (Pythian 4.20-23), and along with other Argonauts produced progeny from the union with the Lemnian women ( $254 \mathrm{ff}$.): 'for it was in those foreign furrows that the fated days and nights received the seed of your family's radiant prosperity, for there the family (yćvoৎ) of Euphamus was planted' (Race's transl., adapted). From there, they went to Sparta and thence to Thera.

We may note that this 'rooting' is based on the genealogy of the kingly family alone, not the whole community of Cyrene, and the matter of the Minyans (below) is also concentrated upon a few families. It is thus a genealogy of the elite, not the community-based tradition of the creation of the settlement sent out from Thera to Cyrene that we see in Herodotus (4.145-159) and the oath of the settlers (ML 5 = SEG IX 3). Moreover, Herodotus' account of the foundation of Cyrene was written after the fall of the monarchy and bears signs of a post-monarchic readjustment in the traditions, as Giangiulio noted in an important paper. ${ }^{13}$ I would depart slightly from this position, however, in pointing out that even after the monarchy the impressive Battiad-centred traditions were surely alive and continuing, even though they will obviously have changed slightly. Secondly, I would put more stress on the importance of performance, genre and social context in which the traditions were selected and retold as an essential influence on what was actually said. ${ }^{14}$ Herodotus was far removed from the social and performance contexts of the Pindaric victory ode, and was able to offer different nuances and different aspects of the Cyrene story without fear of offence. His account of Cyrene ended with the strikingly negative and horrifying account of Pheretime, mother

12 See Giangiulio 2001, esp. 135 for evidence of 6th c. poet Eugammon of Cyrene. For polis tradition and monarchy, Thomas 1989, 172 with n. 39, 196-8; Vansina 1985, 148 ff.

13 Giangiulio 2001, 128 and $n$.

14 Giangiulio 2001, esp. 135-6, stresses more the diachronic division between monarchic and post monarchic periods, if I have correctly understood the argument which occasionally seems forced. See Aly, on the other hand, 1921, 135-40, for the 'folk-tale' units. 
of Arcesilaus, who succeeded in bringing the Persians into Libya (note the end of Book 4).

Nevertheless, Herodotus went into considerable detail on the Therans' very earliest ancestors, those Minyae who left Lemnos and settled in Lacedaemon (4.145-8). He launches into this first before the story of Cyrene's myth of origin and the Persian expedition against Libya (he needs 'to narrate this first', 4.145.1:

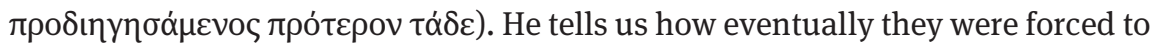
leave Sparta, and led by Theras they went to the island of Thera. The comparison with Pindar is fascinating. For it is striking that Herodotus does not mention Euphemus in his own right as a prominent leader in the events narrated, though he knows of the lineage and calls Battus 'son of Polymnestus, of the Minyan family of the Euphemidae' (4.150.2); nor does he give the tale of the clod of earth so prominent in Pythian 4 in justifying Battiad legitimacy. It is also striking that he mentioned various ancestors of Theras (4.147.1), and talked of Theras acting for a while as regent for his nephews. It is therefore clear first that Pindar was not the source or not the sole source for Herodotus. ${ }^{15}$ There is also good reason to think that the genealogical intricacy is such that some kind of genealogical tradition of a quite careful type might have been available, perhaps a form of genealogical poetry (see n.12). But though Herodotus does not treat the tale of Euphemus, he narrates the tradition of the Minyae at Sparta, which we would regard as equally mythical and fantastical: not only that, the Minyae narrative makes clear that Minyae and the Minyan legacy were an important part of the story of Thera and Cyrene, and provided an ancestor for the Aegeidae in Sparta (4.149). ${ }^{16}$

Let us look more closely at Herodotus' long narrative of the tale of the grandsons of the Argonauts who were expelled from Lemnos and fled to Sparta as their ancestral land (4.145-148). The tale of the Minyae who start by encamping on Mount Taygetus is engagingly told and narrated at length with circumstantial explanations. ${ }^{17}$ It shows all the leisurely repetition of the traditional tale in Herodotus. They lit fires on Taygetus, and this attracted attention. Messengers were sent by the nearby Spartans and after some exchanges land was granted to them. However the Minyae started to act with increasing hybris, having designs on the

15 As Giangiulio 2001 points out; cf. p. 124-5 for a suggestion of written genealogical material, as well as oral, for both Pindar and Herodotus.

16 I do not think we can say, therefore, that Herodotus does not think Battus is descended from Euphemus pace Giangiulio 2001, 128 and n. 46: 'Battus' link with all the Argonautic and Minyan background is completely missing', apparently refers to the Cyrenean traditions. Herodotus 4.145-8 is in his own voice.

17 See Corcella 2007, on 4.145.3 for theories about the Minyae's historical connection with Sparta and Thessaly. Aly 1921, 138-40 for folk-tale motifs here. 
kingship, and the Spartans thereupon decided to murder them. As their first step they threw them into prison. There follows a classic tale of disguise and escape from prison: their Spartan wives visited them in prison ('because executions are always done at night') and they exchanged clothes with the men. And thus the Minyae escaped. Meanwhile Theras, a Cadmeian at Sparta, was intending to leave to join his kin in the island later called Thera (they are apparently there

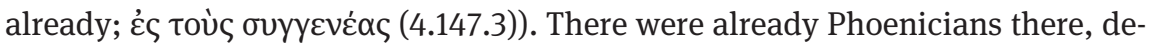
scendants of Membliarus, son of Phoenician Poeciles. And Theras took some of the Minyans with him to Thera - but not all, as Herodotus carefully explains. The detail is fine and exact: for example, Herodotus gives the names of the six towns near Elis settled by the Minyans who did not travel to Thera, and 'most of them were destroyed in my own time by the Eleans' (148.4).

We must be seeing the tip of a raft of origin stories and aetiologies which place Minyans in several parts of the Peloponnese, and which have all been woven into Herodotus' grander narrative. This is not simply a good story with circumstantial narrative elements, but it is tied to places where Minyans were thought to have settled; not simply 'folktales' with nameless actors and generic places, but specific, geographically based stories. It shows the tricks so often found in the oral folktale, ${ }^{18}$ but it is also offering aitia for various settlements in the Peloponnese as well as Thera. So we seem to be entering into a web of legends, aetiological myths, origin stories, all relating to mainland Greece and in particular the Peloponnese (not necessarily, of course, with a basis in historical reality). Pindar knows of the Minyae coming from Lacedaemon to Thera, but the ode only hinted briefly at this. ${ }^{19}$ Herodotus had carefully explained how some of the Minyae did not go to Thera; Pindar had implied that they all did (Pythian 4.256-9). Herodotus said nothing about the fantastic elements of the Euphemus tale as told in Pindar, where a god gave Euphemus a clod of earth; he ignored the myth of Apollo and the nymph Cyrene which is told in Pindar Pythian 9. Indeed, while Pindar made so much of the gift of the clod of earth which thus 'gave' Libya to the Therans, ${ }^{20}$ Herodotus only had a slightly similar aetiological tale which would legitimise Spartan colonising in Libya centred on Jason and the Argonauts

18 Cf. Dewald 2012, 81 with n. 48 for further tricks, with important proviso on the reinforcing of Greek values. Aly 1921, 138 ff. offers parallels for folk-tale motifs, esp. for the wives, postulating 'joins'.

19 Minyae in Lacedaemon: Pythian 4.48-49, a brief reference to setting out from Lacedaemon in Medea's prophecy; 257-9, 'and after joining the abodes of Lacedaemonians, in time they settled on the island once called Calliste' (Race, adapted). Note also that Euphemus came originally from Taenarus in Lacedaemon, Pythian 4.173-5. Malkin 1994, $174 \mathrm{ff}$.

20 See Malkin 1994, 174-81 on significance of the clod, a 'double legitimation'. 
at Lake Tritonis, and it involved a tripod, not a clod (4.178-9). This is placed not as part of the story of Cyrene at all, but within his survey of ever remoter areas and tribes going west to more distant parts of Libya. Jason had arrived there not via a heroic journey overland carrying the ship, as in Pindar, but simply blown off course to Libya on the way to Delphi (and the Libyans promptly hid the tripod in the hope that the prophecy would not be fulfilled!).

Herodotus narrates this all authoritatively, and as far as one can see, without the slightest hint of doubt about its truth value. He ends by saying that Lacedaemonians and Therans agrees up to this point, but from now on he gives the Theran tale (150.1), essentially presenting the Minyae part of the tale as uncontroversial - at least based on Lacedaemonian and Theran belief (unless this is distancing himself). We can contrast his later rationalisation of the tendency of the Delphic oracle, for he explicitly reinterprets the Battus oracle on the grounds that Battus was Libyan for 'king', and suggests that Apollo was hinting at that fact, rather than using Battus' real name (4.155.1-3) - so much for the Theran and Cyrenean versions. ${ }^{21}$

However Herodotus combined or connected this tale of the Minyans and their various exploits, he seems to accept it and to believe, like Pindar, that this remote past is relevant to the story of Cyrene. This is important. In this as in so many colonisation tales, the 'origins' seem to get pushed ever further back. So how and why is this acceptable? Presumably partly purely because they have their own authority and immovability as ‘tradition'. Secondly, surely Herodotus has quietly rationalised the tales in some way, removing some of the more fantastical elements. In fact the tale of the Minyae presented by Herodotus is remarkably similar to the tale of how the Therans eventually reached Cyrene, yet another tale of displacement, settlement, problems with local inhabitants (Spartans, Libyans) and another relocation. Moreover, while Pindar's narrative was inevitably tied to the social setting and position of the honorand, Herodotus' could be independent from that group and more cosmopolitan, taking in the Panhellenic sweep of a whole web of traditions. He could not really resolve the problem of the authority of these traditions, despite their absurd age, and it would seem this was simply because they had traditional weight. Though he carefully separated the $\lambda$ óyo that one can 'know' from the ones that can be questioned and rationalised in the Proem (1.5.3), it would seem that many distant $\mu$ vooı just had to be retold, perhaps with unmarked rationalisation. Perhaps Herodotus' tacit omission of certain

21 I leave aside the Cyrenean version and controversy over the division of the tales: excellent summary with extensive bibliography in Corcella 2007 on Book 4 ad loc. See also Giangiulio 2001, and references there. 
fantastic elements in the tradition used by Pindar gave greater credence to what was left. Thus while Pindar's Euphemus received the clod, in Herodotus (as we saw) a similar story was hived off to a geographical description and attributed to Triton and Jason. One must imagine that these versions were retold and handed down, altering in the process, by poets, communities Theran and Peloponnesian, and any whose business was to recall the Minyae. Moreover while Pindar or other poets could be allusive because the main tales were known, the historian sets out the whole narrative, and perhaps that very process of combining separate narratives itself gave a new authority of completeness.

Alongside these hints of popular stories with the colourful elements of the folktale (the Minyae's escape from prison, Phronime's escape from drowning), we have a distinct rationalising process in the careful tying up of loose ends. The comparison with Pindar allows us to analyse how the historian fills out the gaps, completes the story and, moreover, makes it logical in political terms. Thus Herodotus explained that since the Minyae married Spartan wives, they gave 'to others' their Lemnian wives (who had come with them) (4.145.5). The Minyae in Lacedaemon got privileges and then started to demand more. The Spartans accepted the Minyae because the sons of Tyndareus had also sailed in the Argo. The executions in Sparta are only ever carried out at night (a nice piece of pseudoakribeia to explain how the trick worked). The wives of the Minyae were beyond suspicion because they were all astai and daughters of the foremost Spartiates (4.146.3). In Sparta, some of the Minyae stay behind, some move on to Thera.

We sense instinctively that none of this would feature in a Pindaric ode, at least not in this form. Nor would the other story which occurs later in Herodotus' Battus narrative about the rescue of Battus' mother Phronime which is offered as the Cyrenean version. ${ }^{22}$ Daughter of a king, Phronime was supposed to be drowned in the sea at the behest of her wicked step-mother on a shocking trumped-up charge, but she was saved by Themiston of Thera (4.154.1-155.1). For Themiston was tricked by the king Etearchus in Crete, Phronime's father, into a promise he did not wish to keep, that he would dispose of her in the sea. He kept his oath by lowering her down into the waves and then hauling her back up while still alive. So she went to live in Thera and with Polymnestus she produced a son Battus. The 入óyos is introduced as the Cyrenean story of Battus, quite different from that of the Therans: 'For they say this: there is a city Oaxus of Crete, in which Etearchus was king, and he had a motherless daughter whose name was

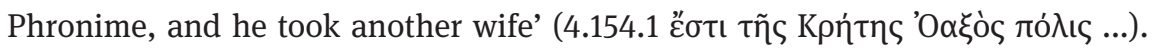
This is the classic beginning of a traditional folktale or fable, and it proceeds with

22 Note also the story of Ladice, 2.181, attached to a statue offered to Aphrodite in Cyrene. 
the familiar motifs of wicked stepmother, treacherous promise, thwarted attempt at murder, escape of young girl. ${ }^{23}$ It sounds like a separate tale which would be retold by itself, and it has an interesting focus on the woman Phronime from Crete. There is also the striking fact that Polymnestus takes her as his concubine:

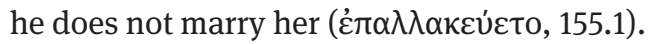

The occurrence of these same names in Thera and Cyrene in later centuries seems to confirm that the same names were current earlier, ${ }^{24}$ and the obvious conclusion is that later aristocratic families saw their remote ancestors in these ancient narratives. The recurring names would paradoxically also seem to confirm the truth-value of the tales.

Thus simply by telling the story of the Minyans being expelled from Lemnos and settling in Sparta, Herodotus was affirming it. We must suspect that some rationalising and selection has occurred, mainly by Herodotus. In this case there are no distancing suggestions, and he attributes it to the Spartans and Therans as if there were no divergences. Despite the possibilities for a tale so connected to the Argonauts, the Minyae tale is not bathed in epic light - indeed it is almost prosaic in the normality of the grandsons of the Argonauts - and it lacks the mythic overtones and fantastical prophecies prominent in the Pindaric evocation of the Argonautic contribution to the founding of Cyrene..$^{25}$ It is rationalised to a level of plausibility which leaves it politically and historically on a par with the later story of the Theran expedition to Cyrene. It offers an example of what the historian Herodotus could do with one of the most evocative of Greek myths.

\section{The Spartan march to Plataea and the Plataea Elegy of Simonides}

We turn now to an episode which was still very recent for Herodotus when he composed his Histories, but which Simonides connected back to the Homeric heroes and which gained through his verse the patina of authority from the epic past. One might think an armed march from Sparta to central Greece held little interest or that the army set out without significant problems. Here is the reverse situation, an episode still alive in memories and very recent traditions, but which

23 See Corcella 2007 on 4.154-6, with Aly 1921, 139 f. on folk motifs; and Corcella 2007 on

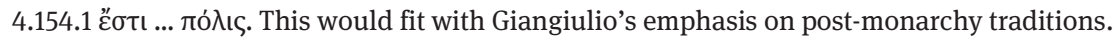

24 See Corcella 2007 on 4.154.1: Etearchus, Phronime, Polymnastus, Themiston, with LGPN.

25 Cf. Dewald 2012 for a recent general analysis of mythic overtones in Herodotus Book 1. 
poetic treatment had tried to turn into myth and legend. By coincidence this also involves the Tyndaridae.

Scholars seem to be somewhat ambivalent about how important the 'New Simonides' is to our reading of Herodotus. Was it a source (of fact) for Herodotus? Boedeker for instance in 2002 seemed sure that 'Herodotus knew this poem as well, and relied on it in certain respects in constructing his own scenario of the decisive battle'. ${ }^{26}$ In the important volume The New Simonides (2001) she listed the convergences and differences, pointing out that Herodotus gives a more complex account, especially where the conflicts between Greek states were concerned, but she also stressed the importance of the Trojan Wars being used as a parallel to the glory of the battle of Plataea and the Persian Wars. The motif of undying fame is there in Simonides and Herodotus; 'The parallels are astonishingly clear'. ${ }^{27}$ This point about parallel undying fame must be right, but we can say more about the divergences, for the conflicts are fundamental to what Herodotus was doing, and indeed in the same volume Aloni was more concerned to stress the quarrels visible in Herodotus' version. ${ }^{28}$ Similarly the commentary of Flower and Marincola is sceptical, pointing out that given the incomplete lines in Simonides, there was a danger of a circular argument, and that on balance it was unlikely that the poem was a source. ${ }^{29}$ More generally, Herodotus might have learned from praise poetry - and Simonides - 'how to see continuities of behaviour and outlook between generations'. ${ }^{30}$

Nevertheless it is worth emphasising that a society which habitually sought heroic ancestors and aitia in the distant past was already comfortable with the idea of heroic parallels, and Simonides might therefore not have been quite so decisive. Certainly he was decisive in making a Homeric image of a very recent battle, and the Homeric elements and influences in Herodotus are abundant. ${ }^{31}$ But Herodotus expanded the range and referents of ' $\kappa \lambda \varepsilon$ ' $о$ ', and now that some

26 Boedeker 2002, 104; referring to Boedeker 2001.

27 2001, $131 \mathrm{ff}$.; quotation at 2002, 108.

28 Aloni 2001, 87, part of his argument for Spartan commission; also Flower/Marincola 2002, Appendix A. The importance of Demeter has also been stressed, fighting around the Demeter shrine and Herodotus' mention of a thoma by the goddess e.g. Boedeker 2001: yet this would be significant enough for many witnesses to mention, and Simonides need not be the only source for Herodotus. It throws into relief Herodotus' avoidance of the Spartan heroes.

29 See 2002, Appendix A, esp. p.317, and p.18f.; Cf. Boedeker 2001, 120-1: 'indeed the account of Plataea in the Histories proved to be the most fruitful resource for both Parsons and West in reconstructing and ordering the fragments'.

30 Marincola 2006, 16.

31 See e.g. Boedeker 2002; de Jong 2002; Pelling 2006, and references there. 
of the initial excitement of the discovery has died down, we can approach this question from another angle. Rather than ask if Simonides was a 'source', we might ask if it could have exerted a rather different kind of influence, influence as a negative source. It is a rare case where one can compare minutely the differences between a poetic celebration and the Herodotean narrative. ${ }^{32}$

It is indeed significant that Simonides brought to the Persian Wars an idealising and heroic aura of the Trojan Wars, and the epic resonances have been extensively discussed: the invocation of the Muses and of Homeric heroes, the creation of $\kappa \lambda \varepsilon$ ćs, and the heroic atmosphere of the Spartan heroes setting off from the Eurotas valley (fr. $11.20 \mathrm{ff}$. $\mathrm{W}^{2}$ ). Perhaps, however, we can also twist this round to point out that while Herodotus could continue the Homeric idea of $\kappa \lambda \varepsilon$ cos, he also tried to diffuse and redistribute it and in some cases, remove $\kappa \lambda \dot{\varepsilon}$ 's altogether. This is not to deny any Homeric echoes in the restored text. But it may also be stressed that Herodotus' narrative of the run-up to the battle of Plataea gives an impression distant indeed from a eulogising or celebratory treatment, let alone an epic treatment. I isolate some elements in this.

First, whose undying fame was at stake? How many different and divergent memories were at stake, how many different polis-centred versions of the Plataea campaign were available? A great many, for any who cared to ask. Herodotus gave the grand roll-call of troops on the Greek side in their battle line-up at the battle of Plataea: Lacedaemonians with Helots, Tegeans, Corinthians with some Potidaeans alongside, Orchomenians, Sicyonians, Epidaurians, Troezenians, others from Lepreum, Mycenae, Tiryns, Phlius, Hermione, Eretria, Styra, Chalcis, Ambracia, Leucas, Anactorium, Pale, Aegina, Megara, Plataea, and finally Athenians (9.28-30). We should add to this recollections from witnesses which might produce accounts differing from the simplified glorification of the Simonides version. A poetic celebration tries to pin down a single version with all the authority of Muse and poet. Herodotus' version not only complicates but undermines and corrects pretentions.

One element we are certain of in Simonides fr. 11. $27 \mathrm{ff} . \mathrm{W}^{2}$ : the Spartans setting out from Eurotas and Sparta accompanied by the horse-rearing sons of Zeus, 'the Tyndarid heroes', and Menelaus, 'leaders of their ancestral polis' ( $\pi \alpha \tau] \rho \omega$ 'ıns

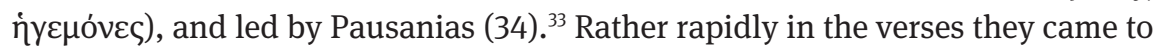
the Isthmus and to Corinth, and to Megara: rapidly indeed, but they are fortified

32 The dangers of using segments reconstructed with help from Herodotus are obvious. However, the march from Sparta is relatively well preserved in the papyrus.

33 The Tyndaridae are restored, but very plausibly: fr. $11.31 \mathrm{~W}^{2}$. 
by the grand, Homeric departure with the heroes. This sounds very like an epiphany: $:^{34}$

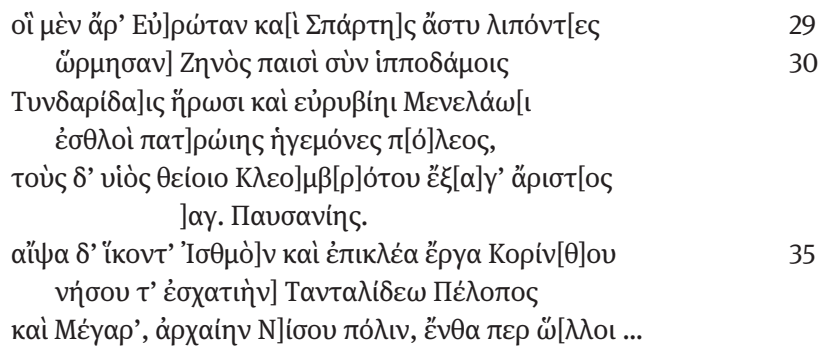

Herodotus' account could hardly be more different, and it is in essence a tale of procrastination, Spartan uncertainty, disguise and cover-up, misrepresentation and the strong impression that they were putting the likely success of Greek resistance at serious risk. A bare resumé of this long section will help underline just how elaborate and long-drawn out were the delays and deliberations at Sparta and the eventual march north from Sparta in Herodotus' version. Thus at $9.6 \mathrm{ff}$., the Athenians despair of the Spartans coming to help them; they move possessions to Salamis and send envoys to Sparta. The Athenian envoys and others give a long speech at Sparta about the Persian offer to let them live in Attica. They accuse the Spartans of breaking their word (9.7). At 9.8f, the Spartan Ephors postpone an answer, and they do this for nearly two weeks. Meanwhile the Isthmus wall is being completed. Finally (9.9) an answer comes through the intervention of Chileus a Tegean, who was influential in Sparta. He pointed out that the Athenians might change their minds and ruin Greece; the wall would not hold the Persians out.

And so finally at 9.10, in secret and before daybreak, the Ephors dispatch 5000 Spartiates and each one takes seven helots with them. This is done without telling the Athenian ambassadors, and they were 'entrusting the expedition to Pausanias son of Cleombrotus'. Herodotus explains how this was the case, for leadership would have gone to the king, Pleistarchus, but he was still a raĩc. King Cleombrotus had been with the troops building the Isthmus wall, but when he sacrificed, there was a solar eclipse; thus he brought back the troops and died soon after.

9.10.3-11.1. This is the crucial section:

34 See Hornblower 2001, $140 \mathrm{ff}$. 


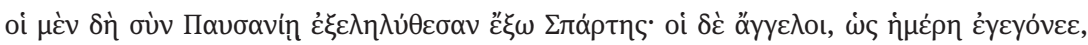

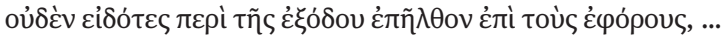

'Some left Sparta with Pausanias, but the envoys, when day broke, know nothing of the departure and went to the ephors',

thinking that they would treat with the Persians. They accuse the Spartans of letting them down. But the Ephors say that the Spartans are already on the march, and there follows more dialogue, questioning, and the Athenians leave rapidly.

And to finish off:

9.12-13: The Argives had been trying to prevent the Spartans marching, and had promised Mardonius to do so. They dispatch a messenger to Mardonius and he thereupon withdraws from Attica for political and strategic reasons, for it was now clear that the Athenians would not come to terms.

9.14: Mardonius also hears that there is another body of Lacedaemonians, distinct from the army of Pausanias and sent on in advance, already in the Megarid. [This is puzzling: so there was already another - secret - Spartan army on the way even when Pausanias and army set out under cover of darkness?]

$9.15 \mathrm{ff}$. There follows the build up of troops and tension in Boeotia, along the Asopus; the narrative proceeds to the factions and quarrelsome interchanges between Greeks and Greeks and between Greeks and Persians. They are still quarrelling about positions at 9.46 .

This could hardly be more different from that heroic but rapid advance in Simonides reaching the Isthmus and Megara without incident or problem, and with the august support of Tyndaridae and Menelaus. The secret departure at night without magnificent fanfare and without gods or heroes in Herodotus contrasts with the fanfare and heroic status of Pausanias in Simonides. ${ }^{35}$ It is secret even from the supposed allies, Athenians and others, and thus in essence a trick is played on them, leading them ever closer to Medising through sheer desperation. Moreover Herodotus' narrative puts the Ephors in control, for they dispatch the army and decide on Pausanias; Euryanax also goes with him. The Athenian envoys, still in the dark, therefore give an angry riposte which is as near as they get to saying that they will Medise. This heightens tension and augments the impression of a merely fragile Greek unity. Herodotus' Pausanias is accompanied by another prominent Spartiate, but of course there is no epiphany, no gods, no local hero.

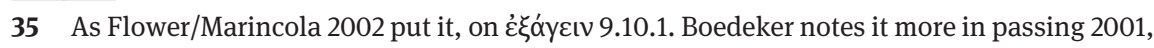
131f.. 
This renders the whole situation more complex politically and more interestingly fraught. What we should surmise is that Herodotus' narrative was deliberately trying to correct and undermine the kind of facile and easy heroic narrative that was created by Simonides (and no doubt others): this disjuncture deserves to be expressed somewhat more forcefully than in some discussions. The Simonides elegy is more than 'a well-known text from which he could differentiate his own version'. ${ }^{36}$ Each city-state created its own memorials, in fierce competition with others, and the Simonides elegy, interesting though it is as a narrative longer than one would have expected, still seems to be creating an image of Spartans as wholly glorious and heroic, and as led by a great leader. If his treatment had influence and wider acceptance, it would serve to efface or dim any memories of what really happened (whatever did happen in those secret meetings in Sparta? Herodotus' narrative may not have the whole story either). It therefore seems to be one unexpectedly well preserved example of the kind of immediate glorification that started occurring soon after the Persian Wars, and which also reappears in the numerous Simonidean epigrams relating to the war. ${ }^{37}$ The Eion epigrams in Athens shortly after also fostered an Homeric aura for the Athenians, but without naming the general in the present (Aeschin. In Ctes. 183-6). Herodotus' last books are scattered with exotic and marvellous stories, epiphanies and ridiculous narratives which he often denies or disproves. While the Simonides elegy lends credence to the importance of epiphanies in the troubled times of the Persian invasions (Hornblower 2001), it should not lead us to suppose that this was all people knew or wanted to hear.

There is also the awkward fact that Pausanias was a highly problematic figure. In the flush of victory, Pausanias was no doubt a great hero, and Simonides' poem seems to reflect that; perhaps the Spartans and Pausanias even commissioned the poem, as Aloni suggested in an important examination of the Spartan dimension (Aloni 2001). But his reputation soon became tarnished by his arrogance, and this arrogance could even serve as an excuse for the Athenians to take over the Hellenic alliance. The poem must belong to that short period in which the Spartans and Pausanias could try to propagate some kind of heroic $\kappa \lambda$ ćos for him while his star was at its height. The historian, however, was not fixed to the contemporary views of that period or to Spartan attempts at self-glorification. He

36 Boedeker 2001, 132: 'The Plataea elegy then may have influenced Herodotus' narrative in negative as well as positive ways, by providing a well-known text from which he could differentiate his own version'.

37 Cf. also Proietti 2015 for interesting examination of other Persian War memorials and memories; Vannicelli 2013, 109-20 for suggestive discussion of Naxos, and 95-108. 
knew of Pausanias' Medising, mentioning his prospective marriage to a Persian nobleman's daughter, though admittedly he added the proviso 'if it is true...', 'having a desire to be túpavvos of Greece' (5.32). So in short it seems likely that Herodotus did much to determine a full and detailed account of the lead-up to the battle precisely because Plataea had been hijacked by Pausanias and the Spartans. Moreover, the poetic celebrations by Simonides and others did so much to lend the aura of an Homeric hero to the participants that the more messy reality needed to be recovered and set out in full detail. We note that Herodotus does not seem to alert us to this in the narrative of the Spartan expedition, he does not emphasise evidence or witnesses, but simply gives the narrative: it is only Simonides' poem which allows us to gather the existence of powerful and perhaps seductive alternatives.

\section{Conclusions}

Let us then bring Herodotus' Plataea narrative and Simonides' elegy into close relation to the several other tales, rumours and anecdotes that abound in the Persian Wars Books. There were the sensational stories about Scyllies the diver who was said to have swum for 80 stades to Artemisium: 'there are lots of other tall

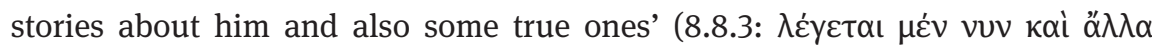

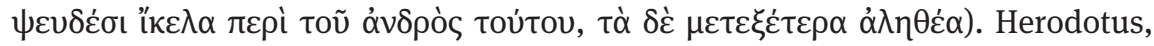
however, thinks he simply reached Artemisium by boat. There were the accounts of divine intervention, some told with caution, like the story told by Philippides to the Athenians and carefully set in indirect speech (6.105; and cf. 6.106). ${ }^{38}$ There were accounts of undignified and cowardly behaviour offered by one or other Greek city about another. Such is the Athenian story told at length and in oratio obliqua about the Corinthians fleeing the battle of Salamis, before being met by a divine ship and turning back (8.94). It is an elaborate and circumstantial tale. In this case, Herodotus goes out of his way to say that this is only an Athenian story, and the rest of the Greeks are witnesses ( $\mu \alpha \rho \tau \nu \rho \varepsilon \varepsilon$ ) to the claims of the Corinthi-

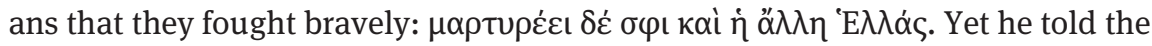
story: why? We may guess that it was a tale that had currency because of Athenian rumours and he thought it important to put it to rest explicitly in this way. ${ }^{39}$

38 Hornblower 2001, 143 f.

39 Note also that Simonides celebrated Corinthian prowess at Plataea: fr. 11.35 and frags. 1516, with Flower/Marincola 2002, Appendix A. 
Sensational accounts evidently existed about the behaviour of the Persians and the Persian king, not to mention the various Greeks, after the battle. Herodotus tells in detail an account of Xerxes' retreat by ship back to Asia which he also refutes in detail: it is a story of tyrannical behaviour which many Greeks would no doubt have loved (8.118-120), with Xerxes getting the Persian nobles to throw themselves overboard to lighten his retreating ship. The story is ringed by the

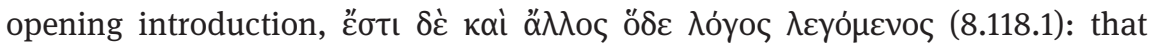
Xerxes in fact retreated by Phoenician ship to Asia but when a storm hit, he made the Persian nobles throw themselves overboard to lighten the load; and when safely on land, he both rewarded the helmsman with a gold crown and then executed him for having destroyed so many Persian lives (8.118.4). Herodotus then refutes it elaborately, first with a spirited claim that had this really happened, no one could possibly doubt that it would have been the Phoenician rowers who

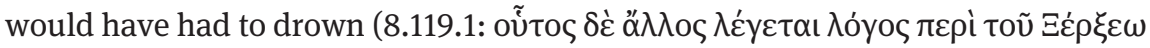

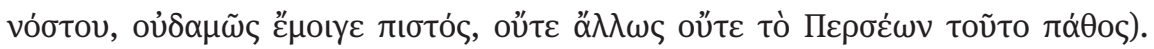

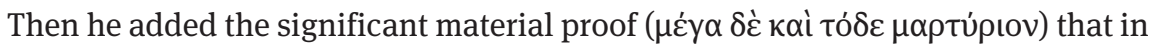
fact Xerxes went via Abdera, gave the Abderites costly gifts, and made a pact of friendship (8.120). Likelihood and the evidence of the Abderites refute the storm story, but he told it perhaps precisely because it was a false story still current and popular.

There were also mysteries which many people claimed to be able to solve. Mardonius' body definitely disappeared, Herodotus says, and it was buried, but

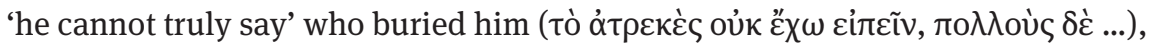
for a great many people claimed to have done so (he names one), and a lot were rewarded accordingly by Mardonius' son (9.84). This sounds like a setting to rest of rumours and fantastic stories, as well as an exposure of the multiplicity of such tales even of this very recent period.

A comparison, then, of Herodotus' treatment with two outstandingly important verse celebrations reveals how the Herodotean narrative might silently correct or silently rationalise from competing and more fantastical traditions. And this helps us define more clearly certain characteristics of Herodotus' method and his mode of narrative. As often repeated, his principle was to tell $\tau \dot{\alpha}$ $\lambda \varepsilon y o ́ \mu \varepsilon v \alpha$ even if he did not believe them (e.g. 2.123.1). But he does not necessarily do this indiscriminately, and sometimes he openly declared a story to be unlikely or simply false. One senses that he was more forgiving for $\lambda$ óyo which constituted a city's views of its origins, but he certainly takes pains to tell and then expose the more absurd, malicious or simply false $\lambda$ óyo relating to the Persian Wars. The refutation of the story of Xerxes' sea-borne retreat (above) is done with the techniques of argument and proof similar to those with which he refuted Greek stories 


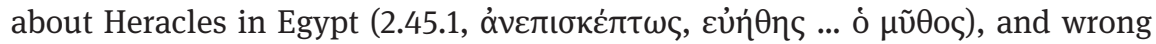
theories about the Nile, and the techniques which also belonged to the nascent arts of persuasion and of scientific enquiry. The ridiculous stories of the Greeks relating to the Egyptians could be paralleled by ridiculous stories related to the Persian Wars. This method effectively uses new tools to rationalise, and it is done explicitly (perhaps unlike the rationalising of Hellanicus or Acusilaus). For the ancient Minyae and the steps by which the Spartans decided to join the defence of central Greece, we are not helped by overt signals of rationalisation or sifting of testimonies, but the poetic treatments help us guess how Herodotus might have selected or rejected various implausible versions and 'false tales'. The differences of genre between epinician and the Simonidean elegy on the one hand and Herodotus' iotopíaı are laid clear. We may suspect that Herodotus' narratives even of mythical times have been significantly rationalised by him from the mass

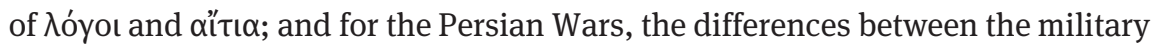
boasts of the city-states could reinforce profound political implications. So while Herodotus undoubtedly signalled an aim to preserve $\kappa \lambda \varepsilon$ ć ${ }^{\circ}$ in the Proem, we should be careful not to assimilate this too rapidly or systematically to the Homeric approach to $k \lambda \varepsilon$ śc. The 'New Simonides' clarifies the kind of tension arising between the authority and memorialising of the poets, and that of the new genre of iotopín and its critical methods. 